\title{
Vitamin D supplementation and strontium ranelate absorption in postmenopausal women with low bone mass
}

\author{
Tatiane Vilaça, Marília Brasílio Rodrigues Camargo, Olguita Ferreira Rocha ${ }^{1}$ and \\ Marise Lazaretti-Castro
}

Bone and Mineral Unit, Division of Endocrinology, Federal University of São Paulo, Rua Borges Lagoa, 800 Vila Clementino, São Paulo SP 04.038-001, Brazil and ${ }^{1}$ Chemical Analysis Division, Technological Center of Minas Gerais (CETEC), Avenida José Cândido da Silveira, 2000 - Horto, Belo Horizonte, Minas Gerais 31.170-495, Brazil
Correspondence should be addressed to T Vilaça Email

vilaca.tatiane@gmail.com

\begin{abstract}
Background: Strontium ranelate is used to treat osteoporosis. Calcium ( $\mathrm{Ca}$ ) and strontium ( $\mathrm{Sr}$ ) have common chemical features and are absorbed by the same pathways. Vitamin $\mathrm{D}$ has a main role in calcium intestinal absorption. The aim of this study was to investigate whether vitamin $D$ status is a determinant of strontium ranelate absorption. Methods: Twenty-five patients with vitamin $D$ deficiency $(25(\mathrm{OH}) \mathrm{D}<50 \mathrm{nmol} / \mathrm{l})$ and 25 with vitamin $\mathrm{D}$ sufficiency $(25(\mathrm{OH}) \mathrm{D}>75 \mathrm{nmol} / \mathrm{l})$ underwent a 4-h oral $\mathrm{Sr}$ overload test. Sr absorption was evaluated as the fraction of absorbed dose and the area under the curve. After the baseline overload test, the deficient patients were treated until reaching sufficient vitamin D levels $(25(\mathrm{OH}) \mathrm{D}>75 \mathrm{nmol} / \mathrm{l})$ and the test was repeated.

Results: Changing vitamin $D$ status from deficient to sufficient resulted in a significant increase in $1,25(\mathrm{OH})_{2} \mathrm{D}(24.97 \pm$ $4.64 \times 34.62 \pm 9.14 \mathrm{pg} / \mathrm{ml}, P<0.001)$ and a reduction in parathyroid hormone $(73.87 \pm 37.50 \times 58.24 \pm 20.13 \mathrm{pg} / \mathrm{ml}, P=0.006)$. Nevertheless, no differences were found in the parameters used to evaluate $\mathrm{Sr}$ absorption between the vitamin $\mathrm{D}$ deficient and sufficient groups. In addition, vitamin D3 replacement in the deficient group did not result in enhanced Sr absorption.

Conclusion: Vitamin D status did not interfere with strontium ranelate absorption. Taking into account the benefits of adequate vitamin $\mathrm{D}$ status in osteoporotic patients, we strongly recommend the treatment of vitamin $\mathrm{D}$ deficiency. However, the data demonstrate that such treatment does not enhance strontium ranelate absorption in patients with mild deficiency.
\end{abstract}

\section{Introduction}

Osteoporosis is a chronic condition characterized by a reduction in bone mass, leading to diminished bone strength and an increased risk of fracture (1). Osteoporotic fractures are associated with a significant increase in morbidity and mortality rates and result in substantial healthcare expenditures. Thus, the aim of treatment is the prevention of fractures (1). Strontium ranelate is currently approved for osteoporosis treatment with significant anti-fracture efficacy $(2,3)$.

Strontium ( $\mathrm{Sr}$ ) is a bivalent ion found as a trace element in human fluids and takes no part in biological cycles $(4,5)$. Like calcium (Ca), $\mathrm{Sr}$ is an alkaline earth metal (5). Previous studies have demonstrated homology between $\mathrm{Ca}$ and $\mathrm{Sr}$ absorption $(4,6,7,8)$. Animal studies using radioactive $\mathrm{Ca}$ and $\mathrm{Sr}$ reveal the same kinetic influx pattern $(7,8,9)$. Moreover, evidence suggests that the transport through enteral cells is mediated by the same membrane carriers $(7,9)$.

Vitamin D is an important factor in Ca absorption $(7,10,11,12,13,14,15)$. As very few foods naturally contain vitamin D and foods are not fortified worldwide, (c) 2014 European Society of Endocrinology Printed in Great Britain
Published by Bioscientifica Ltd. 
the major source for most humans is exposure to sunlight $(16,17)$. Vitamin D deficiency is now recognized as a pandemic $(17,18,19,20)$ and can lead to secondary hyperparathyroidism, increased bone turnover and bone loss, mainly from cortical sites, such as the femoral neck $(13,16,17,21,22,23)$. Thus, all patients with osteoporosis should receive adequate amounts of vitamin D $(24,25)$.

A number of studies suggest that vitamin $\mathrm{D}$ status is a determinant of $\mathrm{Ca}$ absorption $(10,11,12,13)$. While the factors that regulate $\mathrm{Sr}$ have not yet been determined, they are assumed to be similar to those that regulate $\mathrm{Ca}$ metabolism $(7,10,26)$. The aim of the present study was to determine whether vitamin $\mathrm{D}$ status is a determinant of strontium ranelate absorption in patients with low bone mass.

\section{Subjects and methods}

Fifty postmenopausal women evaluated on an outpatient basis at an osteometabolic disease clinic were divided into two groups based on vitamin D status: 25 with vitamin D deficiency - defined as serum levels of 25(OH)D below $50 \mathrm{nmol} / \mathrm{l}$ - and 25 with vitamin D sufficiency - defined as serum levels above $75 \mathrm{nmol} / \mathrm{l}$. The deficient patients were treated with a weekly 50 000-IU cholecalciferol capsule for 8 weeks and the 25(OH)D levels were reassessed (24). Those that did not reach the desirable level $(>75 \mathrm{mmol} / \mathrm{l})$ received a new course of treatment until the expected goal was reached. The patients presented either osteoporosis $(n=34)$ or osteopenia $(n=16)$ based on dual-energy $\mathrm{X}$-ray absorptiometry, had normal values of total $\mathrm{Ca}$, phosphorus $(\mathrm{P})$ and creatinine $(\mathrm{Cr})$ and no history of gastrointestinal disease.

This study received approval from the Human Research Ethics Committee of the Universidade Federal de São Paulo (Brazil). Signed informed consent was obtained from all participants.

\section{Intestinal strontium absorption test}

After an overnight fast, blood was drawn for baseline determinations of $\mathrm{Cr}$, total $\mathrm{Ca}, \mathrm{P}$, albumin, intact parathyroid hormone $(\mathrm{PTH}), 1,25(\mathrm{OH})_{2}$ vitamin D $\left(1,25(\mathrm{OH})_{2} \mathrm{D}\right)$ and $\mathrm{Sr}$. A standard dose of strontium ranelate was then administered. One gram of strontium ranelate was dissolved in $200 \mathrm{ml}$ of deionized water and administered orally. Blood was drawn for Sr determinations at 30, 60, 120 and $240 \mathrm{~min}$. The patients were not permitted to eat during the 4-h $\mathrm{Sr}$ absorption test. The samples were collected in metal-free tubes and centrifuged at $404 \boldsymbol{g}$ for $10 \mathrm{~min}$. The serum was separated and stored at $-20^{\circ} \mathrm{C}$ until analysis.

\section{Analytical methods}

Cr, $\mathrm{P}$ and $\mathrm{Ca}$ were measured using the automated colorimetric method (Olympus AU 640, automated analyzer; Olympus America, Inc., Diagnostic System Division, Melville, NY, USA). Chemiluminescence commercial assays (Elecsys 1010 immunoassay analyzer; Roche Diagnostics) were performed to quantify PTH. Mean intra-assay and inter-assay coefficients of variation were 1.01 and $6.45 \%$ respectively.

The 25(OH)D levels were determined by chemiluminescense immunoassay (LIAISON $25 \mathrm{OH}$ Vitamin D TotalDiaSorin, Stillwater, MN, USA), with mean intra-assay and inter-assay coefficients of variations of 1.62 and $5.61 \%$ respectively.

$1,25(\mathrm{OH})_{2} \mathrm{D}$ was analyzed by RIA following the immunoextraction of the samples (1,25-dihydroxy vitamin D RIA, IDS, Boldon, UK). The coefficient of variation ranged from 7 to $11 \%$ and the recovery rate ranged from 97 to $108 \%$.

$\mathrm{Sr}$ determinations were made using inductively coupled plasma mass spectrometry (Elan DRC-e mass spectrometry, Perkin Elmer Sciex ELAN DRC II, Toronto, Canada). All strontium samples were processed and analyzed in duplicate. Mean values were used. The intraassay coefficient of variation was $4 \%$ and the recovery rates 91-105\%. Sr absorption was analyzed as the fraction of absorbed dose (FAD) at each time (30, 60, 120 and $240 \mathrm{~min}$ ) of the test and the total area under the curve (AUC).

Extracellular fluid was assumed to be $15 \%$ of body weight and FAD was calculated according to the following formula:

FAD $t=\frac{(\operatorname{Sr} t-\operatorname{Sr} 0) \times 15 \% \text { body weight }}{\text { Sr administered dose }}$

The AUC was calculated as the increment (above baseline) in the concentration-time curve over the 240 min of the test, determined by the trapezoid method and expressed as micromoles per litre per minute.

\section{Statistical analyses}

Statistical analyses were performed with the aid of the Statistical Package for the Social Sciences (SPSS) version 19.0 (SPSS, Inc.). Baseline features of the groups were expressed as mean and S.D. For all variables, the Kolmogorov-Smirnov test was used to determine the 
normality of the data. The Student's $t$-test for unpaired data was employed to evaluate baseline features. The FAD of $\mathrm{Sr}$ at each time (30, 60, 120 and $240 \mathrm{~min})$ and the AUC between deficient and sufficient patients were evaluated using the unpaired Student's t-test. The paired Student's $t$-test was used for the comparison of FAD and AUC in the deficient group before and after treatment. Pearson's correlation coefficients were calculated to assess interrelationships between the variables. All tests were two-tailed and the type 1 error level was set to $5 \%$.

\section{Results}

Table 1 displays the characteristics of the participants in the vitamin D sufficient and deficient groups.

No differences were found in the parameters used to evaluate $\mathrm{Sr}$ absorption (FAD at any time and AUC) between the vitamin $\mathrm{D}$ deficient and sufficient groups (Figs 1A, B and 2A).

In the deficient group, the second oral $\mathrm{Sr}$ overload test was performed only when each individual achieved the desirable 25(OH)D level ( $>75 \mathrm{nmol} / \mathrm{l})$. The final mean 25(OH)D concentration was $99.92( \pm 22.17) \mathrm{nmol} / \mathrm{l}$, which was significantly higher than the baseline concentration. A significant increase was also found in $1,25(\mathrm{OH})_{2} \mathrm{D}$ concentration after treatment with cholecalciferol in the deficient group. However, no significant differences were found in any $\mathrm{Sr}$ intestinal absorption parameters in the deficient group before or after treatment. Thus, vitamin D3 replacement in the deficient group did not result in enhanced Sr absorption (Fig. 2B).

Although all patients in both groups presented $1,25(\mathrm{OH})_{2} \mathrm{D}$ within the normal range, a significant difference in $1,25(\mathrm{OH})_{2} \mathrm{D}$ levels was found between the sufficient and deficient groups $(P<0.001)$ at baseline (Fig. 3A). This difference disappeared following treatment for vitamin $\mathrm{D}$ deficiency $(P=0.547)$. A significant positive correlation was found between $25(\mathrm{OH}) \mathrm{D}$ and $1,25(\mathrm{OH})_{2} \mathrm{D}$ (0.573; $P<0.001)$ at baseline. Levels of $1,25(\mathrm{OH})_{2}$ also correlated with the total cholecalciferol doses used $(r=$ $0.335 ; P=0.017)$ and FAD at $120 \min (r=0.305 ; P=0.033)$.

The cholecalciferol dose correlated positively with 25(OH)D levels $(r=0.462 ; P=0.001)$ and negatively with PTH concentrations $(r=-0.357 ; P=0.01)$. An inverse association with borderline statistical significance ( $r=-0.271 ; P=0.05)$ was found between PTH and $25(\mathrm{OH}) \mathrm{D}$ concentrations. PTH was similar in the deficient and sufficient groups $(P=0.174)$ at baseline, but the deficient group experienced a significant reduction following treatment $(P=0.006)$ (Fig. 3B).

\section{Discussion}

We report here the results of a study that evaluated the influence of vitamin D status on strontium ranelate absorption in postmenopausal women, the target population of this medication $(2,3)$. Postmenopausal women are also at risk for vitamin $\mathrm{D}$ deficiency because older individuals spend less time in the sun and older skin has significantly less capacity to synthesize vitamin D from sunlight than the skin of younger people $(18,23)$. In the present study, vitamin $\mathrm{D}$ status, defined according to $25(\mathrm{OH}) \mathrm{D}$ serum concentrations, seems not to be clinically relevant for the strontium ranelate absorption in patients with low bone mass. Only a mild significant positive correlation was found between $1,25(\mathrm{OH})_{2} \mathrm{D}$ levels

Table 1 Characteristics of participants. Data are presented as mean \pm s.D.

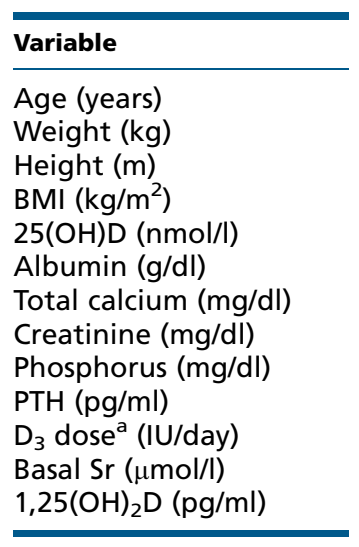

\begin{tabular}{c}
\hline Sufficient $n=25$ \\
\hline $68.56 \pm 7.78$ \\
$59.98 \pm 8.47$ \\
$1.51 \pm 0.05$ \\
$26.03 \pm 3.14$ \\
$98.4 \pm 18.3$ \\
$4.18 \pm 0.27$ \\
$9.26 \pm 0.44$ \\
$0.72 \pm 0.12$ \\
$3.51 \pm 0.51$ \\
$62.28 \pm 18.79$ \\
$1712.4 \pm 724.8$ \\
$0.54 \pm 0.3$ \\
$36.3 \pm 10.2$ \\
\hline
\end{tabular}

\begin{tabular}{c}
\hline Deficient $n=25$ \\
\hline $68.40 \pm 6.49$ \\
$62.87 \pm 8.41$ \\
$1.52 \pm 0.05$ \\
$27.44 \pm 3.46$ \\
$38.5 \pm 13.5$ \\
$4.26 \pm 0.27$ \\
$9.14 \pm 0.44$ \\
$0.71 \pm 0.12$ \\
$3.47 \pm 0.49$ \\
$73.87 \pm 37.5$ \\
$808.76 \pm 689.5$ \\
$0.52 \pm 0.31$ \\
$24.97 \pm 4.63$
\end{tabular}

\begin{tabular}{c}
\hline $\boldsymbol{P}$ \\
\hline 0.937 \\
0.231 \\
0.891 \\
0.154 \\
$<0.001 *$ \\
0.33 \\
0.34 \\
0.836 \\
0.758 \\
0.174 \\
$<0.001$ * \\
0.823 \\
$<0.001 *$ \\
\hline
\end{tabular}

\begin{tabular}{l} 
Normal range \\
\hline NA \\
NA \\
NA \\
$20-25$ \\
$20.0-150.0$ \\
$3.5-5.2$ \\
$8.6-10.2$ \\
$0.5-0.9$ \\
$2.5-4.5$ \\
$15.0-65.0$ \\
NA \\
NA \\
$18.0-78.0$
\end{tabular}

NA, not applicable; $* P<0.05$.

${ }^{\mathrm{a}} \mathrm{D}_{3}$ supplementation dose in use in previous 3 months. 
A

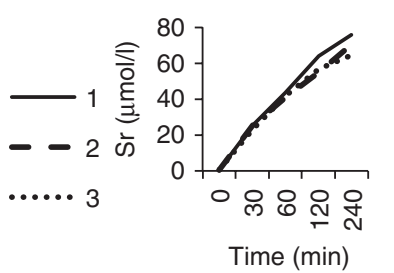

1-Sufficient 2-Deficient before treatment
B

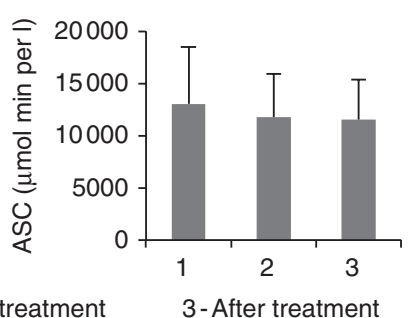

\section{Figure 1}

(A) Profile of mean plasma strontium concentrations during the test in the three groups. (B) Profile of mean AUC in the three groups.

and later fractions of absorbed dose of Sr. As expected, a positive correlation was found between both vitamin $\mathrm{D}$ metabolites $\left(25(\mathrm{OH}) \mathrm{D}\right.$ and $\left.1,25(\mathrm{OH})_{2} \mathrm{D}\right)$ and between cholecalciferol dose in use and $25(\mathrm{OH}) \mathrm{D}$ levels. Changing vitamin $\mathrm{D}$ status from deficient to sufficient resulted in a significant increase in $1,25(\mathrm{OH})_{2} \mathrm{D}$ and reduction in PTH levels (Fig. 2A and B).

The relation between $\mathrm{Sr}$ absorption and the active vitamin $\mathrm{D}$ metabolite (calcitriol) has been previously studied. Bolscher et al. applied a similar test to evaluate the influence of calcitriol on $\mathrm{Sr}$ absorption. Healthy voluntaries were submitted to a basal strontium oral overload test using $2.5 \mathrm{mmol}$ of Sr. After treatment with oral calcitriol, the test was repeated. A 35\% enhance in $\mathrm{Sr}$ absorption was observed. A statistically significant difference was detected in a group of eight volunteers (26).

The effects of cholecalciferol supplementation had also been evaluated, albeit by a different route of administration. Although Khan et al. (27) used $\mathrm{Sr}$ as a surrogate for $\mathrm{Ca}$ absorption, they did not find any change in $\mathrm{Sr}$ absorption before or after an i.m. injection of vitamin D3 in a previously deficient adult population. A single vitamin D3 injection of 600000 IU significantly increased mean 25(OH)D concentration and tended to lower PTH in volunteers with initially low 25(OH)D status, but no effect on $\mathrm{Sr}$ absorption was found (27). Although the study used strontium chloride at a lower $\mathrm{Sr}$ dose $(4.8 \mathrm{mg} / \mathrm{kg})$, the profile described was very similar to that found in the present study using strontium ranelate. The authors also used one of the same parameters to assess strontium absorption (AUC) and found no difference before or after intramuscular cholecalciferol treatment. This result suggests that vitamin D levels are not directly related to Sr absorption, which is in agreement with the present findings.
The evaluation of intestinal $\mathrm{Sr}$ absorption using an oral overload test may be influenced by diet. Animal studies have shown that absorption differs between solid and liquid sources (8). The majority of studies evaluating Sr absorption administered it only with water $(6,26,27$, $28,29,30)$. Some used a standard breakfast with a known Ca content based on the selection against $\mathrm{Sr}$ in favor of $\mathrm{Ca}$ in the intestinal tract $(8,28,30,31)$. A standard breakfast was shown to reduce the Sr FAD at each evaluation time as well as the variance within and between subjects, but the shape of the absorption curves remained unchanged $(27,30)$. The choice of the fasting state and administration of $\mathrm{Sr}$ dissolved in water could raise discussion on the modulating effect of a meal on the transit time through
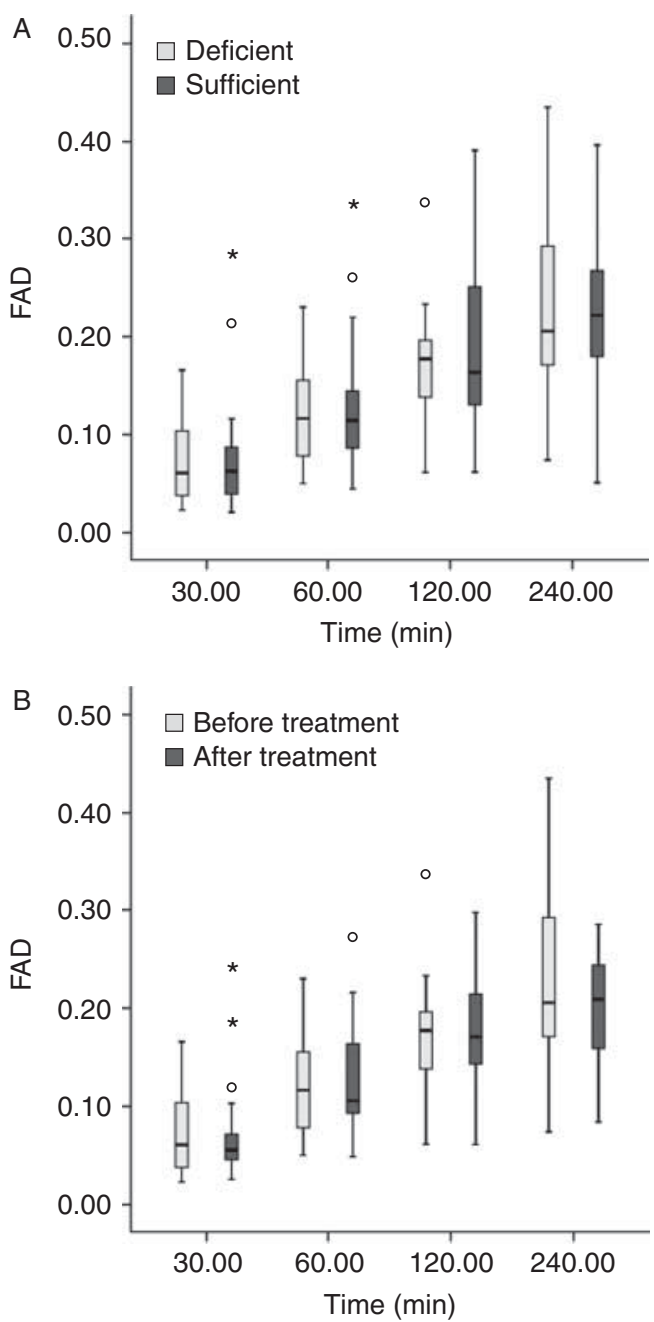

Figure 2

FAD in deficient and sufficient groups $(A)$ and before and after treatment (B). 

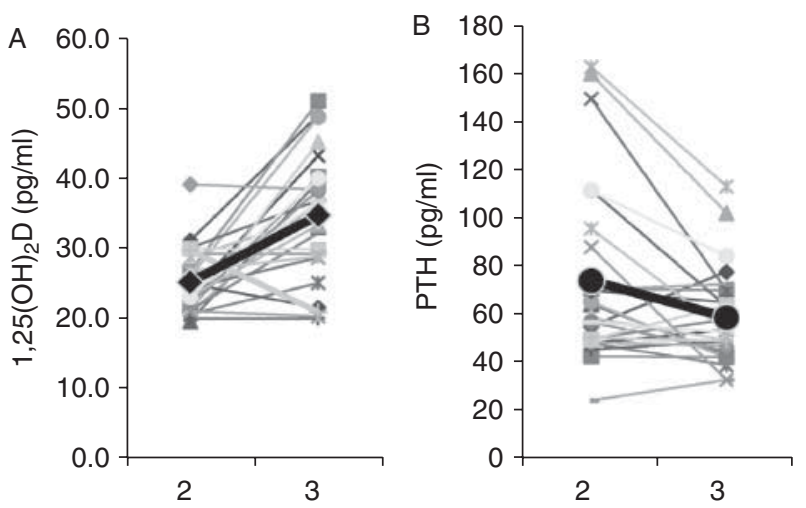

\section{Figure 3}

Profile of $1,25(\mathrm{OH})_{2} \mathrm{D}(\mathrm{A})$ and PTH $(\mathrm{B})$ in the deficient group before (2) and after treatment (3). The mean values are emphasized.

the stomach and intestine. On the other hand, there is a lack of uniformity in the composition of the meals applied in the various tests described in the literature $(27,30,31)$. Furthermore, the recommendation for the therapeutic use of strontium ranelate is that it should be taken at least $2 \mathrm{~h}$ before any meal. Therefore, the test in the present study was standardized with the fasting state.

The present study has a limitation that should be addressed. The presence of any gastrointestinal problem that could interfere with the absorption performance of the patients was not formally excluded, unless by the medical history. No specific evaluation was performed for that.

The two groups (sufficient and deficient) were similar with regard to baseline features, except for $25(\mathrm{OH}) \mathrm{D}$ (by design), 1,25(OH $)_{2} \mathrm{D}$ and cholecalciferol dose in use. Levels of $25(\mathrm{OH}) \mathrm{D}$ and $1,25(\mathrm{OH})_{2} \mathrm{D}$ were correlated. At higher $25(\mathrm{OH}) \mathrm{D}$ concentrations and normal PTH, the correlation between the two vitamin $\mathrm{D}$ metabolites became stronger $(r=0.670 ; P<0.001)$. Thus, it seems that $1,25(\mathrm{OH})_{2} \mathrm{D}$ is a function of $25(\mathrm{OH}) \mathrm{D}$, especially in individuals with adequate vitamin $\mathrm{D}$ status. At lower levels, secondary hyperparathyroidism is triggered to avoid the drop in $1,25(\mathrm{OH})_{2} \mathrm{D}$. Therefore, cholecalciferol supplementation is important to maintain adequate levels of $25(\mathrm{OH}) \mathrm{D}$ and $1,25(\mathrm{OH})_{2} \mathrm{D}$ as well as to avoid the secondary elevation of PTH and its harmful effects.

The vitamin $\mathrm{D}$ thresholds chosen to define deficiency $(<50 \mathrm{nmol} / \mathrm{l})$ and sufficiency $(>75 \mathrm{nmol} / \mathrm{l})$ were determined in a manner to avoid debate. Despite the controversy over optimal levels of $25(\mathrm{OH}) \mathrm{D}$, most experts agree levels less than $50 \mathrm{nmol} / \mathrm{l}(20 \mathrm{ng} / \mathrm{ml})$ characterize vitamin $\mathrm{D}$ deficiency $(24,25,32)$ and there is also consensus regarding levels above $75 \mathrm{nmol} / \mathrm{l}(30 \mathrm{ng} / \mathrm{ml})$ as sufficient $(24,25,32)$. Thus, the different vitamin $D$ status in the two groups evaluated herein was unquestionable.

$\mathrm{Sr}$ absorption has previously been studied mainly based on the homology with Ca. Although Dumond et al. (33) suggest that Sr transport is exclusively passive, other authors have found evidence regarding active intestinal $\mathrm{Sr}$ transport and indications for a common mechanism with $\mathrm{Ca}(4,6,7,8)$. Bolscher et al. (26) found a stimulatory effect of $1,25(\mathrm{OH})_{2} \mathrm{D}$ in $\mathrm{Sr}$ absorption. The authors evaluated $\mathrm{Sr}$ absorption in healthy volunteers before and after treatment with oral calcitriol and found enhanced $\mathrm{Sr}$ absorption as measured by FAD at $240 \mathrm{~min}$ and AUC. However, no correlation between serum levels of $1,25(\mathrm{OH})_{2} \mathrm{D}$ and $\mathrm{Sr}$ absorption was demonstrated. In the present study, $1,25(\mathrm{OH})_{2} \mathrm{D}$ correlated positively with FAD at $120 \mathrm{~min}$. Although the association was found in only one of the variables analyzed, this result lends strength to the possibility of an effect of $1,25(\mathrm{OH})_{2} \mathrm{D}$ on $\mathrm{Sr}$ absorption.

There is controversy over the association between the concentration of $25(\mathrm{OH}) \mathrm{D}$ and $\mathrm{Ca}$ absorption, which could be carefully extrapolated for Sr. A number of authors have found positive correlations $(13,16,21,22,31,34)$, whereas others have not $(15,22,29,35,36)$. Graff et al. (35) found no significant difference in fractional Ca absorption between children with and without active rickets, despite the lower 25(OH)D concentrations in the former group. Need \& Nordin (36) evaluated 461 postmenopausal women and found no association between radiocalcium absorption and serum 25(OH)D. Similarly, Aloia et al. (15) found no association between serum 25(OH)D concentrations and radiocalcium absorption efficiency in healthy women aged 20-80 years. Although Heaney et al. (13) proposed that the threshold for maximum calcium absorption was 80-90 nmol/1, other evidence suggested different values. Animal studies showed that in rats and dogs, little amounts of vitamin D (10 and $20 \mathrm{IU}$ respectively) were enough to reach the maximum calcium absorption (37, 38). In humans, Need et al. (39) described impairment of calcium absorption only with vitamin D levels lower than $10 \mathrm{nmol} / \mathrm{l}(4 \mathrm{ng} / \mathrm{ml})$. In recent evaluation studies on the effect of vitamin D supplementation in calcium absorption among postmenopausal women, Gallagher et al. found out that it is correlated with serum $1,25(\mathrm{OH})_{2} \mathrm{D}$, but not with $25(\mathrm{OH}) \mathrm{D}(42,43)$. They suggested that malabsorption occurs only in severe vitamin $\mathrm{D}$ deficiency $(25(\mathrm{OH}) \mathrm{D}<10 \mathrm{ng} / \mathrm{ml})$, when the lack of substrate causes a decrease in $1,25(\mathrm{OH})_{2} \mathrm{D}$ production. Our data are in agreement with these findings as our subjects were not severely deficient. 
All patients in the present study had $1,25(\mathrm{OH})_{2} \mathrm{D}$ within the normal range, regardless of their vitamin $\mathrm{D}$ status. This finding is in agreement with the idea that in the absence of kidney failure, vitamin D deficiency must be very severe to cause deficiency in $1,25(\mathrm{OH})_{2} \mathrm{D}(15,36)$. It seems that at low levels of $25(\mathrm{OH}) \mathrm{D}$, secondary hyperparathyroidism enhances the conversion of $25(\mathrm{OH}) \mathrm{D}$ to $1,25(\mathrm{OH})_{2} \mathrm{D}$, thereby acting as a protective mechanism. Despite the tight control of $1,25(\mathrm{OH})_{2} \mathrm{D}$ production, a significant increase in $1,25(\mathrm{OH})_{2} \mathrm{D}$ was found following cholecalciferol treatment. This has previously been described in a trial that analyzed the effect of vitamin D replacement on musculoskeletal parameters in schoolchildren (40). Although the crossreactivity of $1,25(\mathrm{OH})_{2} \mathrm{D}$ with $25(\mathrm{OH}) \mathrm{D}$ is estimated to be $<0.01 \%$, this possibility cannot be discarded (41).

\section{Conclusion}

In summary, the correction of mild vitamin D deficiency is not linked with optimization of strontium ranelate absorption. However, the importance of vitamin D for bone health is irrefutable. Taking into account the benefits of correcting vitamin D status in osteoporotic patients, we strongly recommend the treatment of vitamin D deficiency. However, the data demonstrate that such treatment is not relevant to enhance strontium ranelate absorption during treatment for osteoporosis.

\section{Declaration of interest}

Strontium ranelate was kindly provided by Servier. An unconditional grant was received from Servier for part of the 25-hydroxyvitamin $D$ and Strontium measurements. All authors have nothing to disclose.

\section{Funding}

T Vilaça has received grant support from Brazilian Federal Agency for Support and Evaluation of Graduate Education (CAPES). This work was supported by FAPESP (Fundação de Amparo a Pesquisa do Estado de Sao Paulo-São Paulo Research Foundation) (grant number 200855677).

\section{Acknowledgements}

The authors are grateful to Dr Ivan Rassi for assistance in the 25(OH)D measurements and Gianni dos Santos for her advice concerning the statistical analysis.

\section{References}

1 NIH Consensus Development Panel on Osteoporosis Prevention, Diagnosis, and Therapy. Osteoporosis prevention, diagnosis, and therapy. Journal of the American Medical Association 200114 785-952.
2 Meunier PJ, Roux C, Seeman E, Ortolani S, Badurski J, Spector T, Cannata J, Balogh A, Lemmel EM, Pors-Nielsen S et al. The effects of strontium ranelate on the risk of vertebral fracture in women with postmenopausal osteoporosis. New England Journal of Medicine $2004 \mathbf{3 5 0}$ 459-468. (doi:10.1056/NEJMoa022436)

3 Reginster JY, Seeman E, De Vernejoul MC, Adami S, Compston J, Phenekos C, Devogelaer JP, Diaz Curiel M, Sawicki A, Goemaere S et al. Strontium ranelate reduces the risk of nonvertebral fractures in postmenopausal women with osteoporosis: Treatment of Peripheral Osteoporosis (TROPOS) study. Journal of Clinical Endocrinology and Metabolism 200590 2816-2822. (doi:10.1210/jc.2004-1774)

4 Vezzoli G, Baragetti I, Zerbi S, Caumo A, Soldati L, Bellinzoni P, Centemero A, Rubinacci A, Moro GL \& Bianchi G. Strontium absorption and excretion in normocalciuric subjects: relation to calcium metabolism. Clinical Chemistry 199844 586-590.

5 Ober J \& Polyak D. US Geological Survey Minerals Yearbook 2007, www.minerals.usgs.gov/minerals.

6 Sips AJA, Van der Vtjgh WJF, Barto R \& Netelenbos JC. Intestinal strontium absorption: from bioavailability to validation of a simple test representative for intestinal calcium absorption. Clinical Chemistry 1995 41 1446-1450.

7 Papworth DG \& Patrick G. The kinetics of influx of calcium and strontium into rat intestine in vitro. Journal of Physiology $19702 \mathbf{2 1 0}$ 999-1020.

8 Marcus CS \& Lengemann W. Absorption of Ca45 and Sr85 from solid and liquid food at various levels of the alimentary tract of the rat. Journal of Nutrition 196277 155-160.

9 Dahl SG, Allain P, Marie PJ, Mauras Y, Boivin G, Ammann P \& Tsouderos Y. Incorporation and distribution of strontium in bone. Bone 200128 446-453. (doi:10.1016/S8756-3282(01)00419-7)

10 Bronner F. Calcium absorption - a paradigm for mineral absorption. Journal of Nutrition $1998 \mathbf{1 2 8}$ 917-920.

11 Wasserman RH \& Fullmer CS. Vitamin D and intestinal calcium transport: facts, speculations and hypotheses. Journal of Nutrition 1995 125 1971S-1979S.

12 Lieben L, Carmeliet G \& Masuyama R. Calcemic actions of vitamin D: effects on the intestine, kidney and bone. Best Practice \& Research. Clinical Endocrinology \& Metabolism 200525 561-572. (doi:10.1016/ j.beem.2011.05.008)

13 Heaney RP, Dowell S, Hale CA \& Bendich A. Calcium absorption varies within the reference range for serum 25-hydroxyvitamin D. Journal of the American College of Nutrition 200322 142-146. (doi:10.1080/ 07315724.2003.10719287)

14 Bullamore JR, Wilkinson R, Gallagher JC \& Nordin BEC. Effect of age on calcium absorption. Lancet 19702 535-537. (doi:10.1016/S01406736(70)91344-9)

15 Aloia JF, Chen DG, Yeh JK \& Chen H. Serum vitamin D metabolites and intestinal calcium absorption efficiency in women. American Journal of Clinical Nutrition 201092 835-840. (doi:10.3945/ajcn.2010.29553)

16 Heaney RP. 25-Hydroxyvitamin D and calcium absorption. American Journal of Clinical Nutrition 201193 220-221. (doi:10.3945/ajcn. 110.004838)

17 Holick M. Vitamin D deficiency. New England Journal of Medicine 2007 357 266-281. (doi:10.1056/NEJMra070553)

18 Saraiva GL, Cendoroglo MS, Ramos LR, Araújo LM, Vieira J, Kunii I, Hayashi LF, Corrêa MP \& Lazaretti-Castro M. Influence of ultraviolet radiation on the production of 25 hydroxyvitamin $\mathrm{D}$ in the elderly population in the city of São Paulo (23 degrees $34^{\prime}$ S), Brazil. Osteoporosis International 200516 1649-1654. (doi:10.1007/s00198-005-1895-3)

19 Lips P, Duong T, Oleksik A, Black D, Cummings S, Cox D \& Nickelsen T. A global study of vitamin D status and parathyroid function in postmenopausal women with osteoporosis: baseline data from the multiple outcomes of raloxifene evaluation clinical trial. Journal of Clinical Endocrinology and Metabolism 200186 1212-1221.

20 Chapuy MC, Preziosi P, Maamer M, Arnaud S, Galan P, Hercberg S \& Meunier PJ. Prevalence of vitamin D insufficiency in an adult normal 
population. Osteoporosis International 19977 439-443. (doi:10.1007/ s001980050030)

21 Heaney RP, Barger-Lux MJ, Dowell MS, Chen TC \& Holick MF. Calcium absorptive effects of vitamin D and its major metabolites. Journal of Clinical Endocrinology and Metabolism 199782 4111-4116.

22 Heaney RP. Vitamin D in health and disease. Clinical Journal of the American Society of Nephrology 20083 1535-1541. (doi:10.2215/ CJN.01160308)

23 Holick MF \& Chen TC. Vitamin D deficiency: a worldwide problem with health consequences. American Journal of Clinical Nutrition 200887 1080S-1086S.

24 Holick MF, Binkley NC, Bischoff-Ferrari HA, Gordon CM, Hanley DA, Heaney RP, Murad MH \& Weaver CM. Evaluation, treatment, and prevention of vitamin D deficiency: an Endocrine Society clinical practice guideline. Journal of Clinical Endocrinology and Metabolism 2001 96 1911-1930. (doi:10.1210/jc.2011-0385)

25 Briot K, Cortet B, Thomas T, Audran M, Blain H, Breuil V, Chapuis L, Chapurlat R, Fardellone P, Feron JM et al. 2012 update of French guidelines for the pharmacological treatment of postmenopausal osteoporosis. Joint, Bone, Spine 201279 304-313. (doi:10.1016/j.jbspin. 2012.02.014)

26 Bolscher MD, Netelenbos JC, Barto R \& Van der Vijgh WJF. Strontium as a marker for intestinal $\mathrm{Ca}$ absorption: the stimulatory effect of calcitriol. Clinical Chemistry 200046 248-251.

27 Khan AH, Rohra DK, Saghir SA, Udani SK, Wood RJ \& Jabbar A. No change in calcium absorption in adult Pakistani population before and after vitamin $\mathrm{D}$ administration using strontium as surrogate. Osteoporosis International 20133 1057-1062. (doi:10.1007/s00198-0122007-9)

28 Milsom S, Ibbertson K, Hannan S, Shaw D \& Pybus J. Simple test of intestinal calcium absorption measured by stable strontium. BMJ 1987 295 231-234. (doi:10.1136/bmj.295.6592.231)

29 Sips AJ, Netelenbos JC, Barto R, Lips P \& van der Vijgh WJ. One-hour test for estimating intestinal absorption of calcium by using stable strontium as a marker. Clinical Chemistry 199440 257-259.

30 Sips AJ, van der Vijgh WJ, Barto R \& Netelenbos JC. Intestinal absorption of strontium chloride in healthy volunteers: pharmacokinetics and reproducibility. British Journal of Clinical Pharmacology 1996 41 543-549. (doi:10.1046/j.1365-2125.1996.33411.x)

31 Zittermann A, Heer M, Caillot-Augusso A, Rettberg P, Scheld K, Drummer C, Alexandre C, Horneck G, Vorobiev D \& Stehle P. Microgravity inhibits intestinal calcium absorption as shown by a stable strontium test. European Journal of Clinical Investigation $2000 \mathbf{3 0}$ 1036-1043. (doi:10.1046/j.1365-2362.2000.00682.x)

32 Ross AC, Manson JE, Abrams SA, Aloia JF, Brannon PM, Clinton SK, Durazo-Arvizu RA, Gallagher JC, Gallo RL, Jones G et al. The report on dietary reference intakes for calcium and vitamin D from the Institute of Medicine: what clinicians need to know. Journal of Clinical Endocrinology and Metabolism 201196 53-58. (doi:10.1210/ jc.2010-2704)

33 Dumont PA, Curran PF \& Solomon AK. Calcium and strontium in rat small intestine. Their fluxes and their effect on Na flux. Journal of General Physiology 196043 1119-1136. (doi:10.1085/jgp.43.6.1119)

34 Zittermann A, Scheld K \& Stehle P. Seasonal variations in vitamin D status and calcium absorption do not influence bone turnover in young women. European Journal of Clinical Nutrition 1998 52 501-506. (doi:10.1038/sj.ejcn.1600591)

35 Graff M, Thacher TD, Fischer PR, Stadler D, Pam SD, Pettifor JM, Isichei CO \& Abrams SA. Calcium absorption in Nigerian children with rickets. American Journal of Clinical Nutrition 200480 1415-1421.

36 Need AG \& Nordin BE. Misconceptions - vitamin D insufficiency causes malabsorption of calcium. Bone 200842 1021-1024. (doi:10.1016/ j.bone.2008.01.012)

37 Mellanby E. The rickets-producing and anti-calcifying action of phytate. Journal of Physiology 1949109 488-533.

38 Carlsson A \& Lindquist B. Comparison of intestinal and skeletal effects of vitamin D in relation to dosage. Acta Physiologica Scandinavica 1955 35 53-55. (doi:10.1111/j.1748-1716.1955.tb01263.x)

39 Need AG, O'Loughlin PD, Morris HA, Coates PS, Horowitz M \& Nordin BEC. Vitamin D metabolites and calcium absorption in severe vitamin D deficiency. Journal of Bone and Mineral Metabolism 200823 1859-1863.

40 Fuleihan GE, Nabulsi M, Tamim H, Maalouf J, Salamoun M, Khalife H, Choucair M, Arabi A \& Vieth R. Effect of vitamin D replacement on musculoskeletal parameters in school children: a randomized controlled trial. Journal of Clinical Endocrinology and Metabolism 200691 405-412. (doi:10.1210/jc.2005-1436)

41 Hollis B. Assessment and Interpretation of circulating 25-hydroxyvitamin D and 1,25-dihydroxyvitamin D in the clinical environment. Endocrinology and Metabolism Clinics of North America 201039 271-286. (doi:10.1016/j.ecl.2010.02.012)

42 Ardissino G, Schmitt CP, Bianchi ML, Daccò V, Claris-Appiani A \& Mehls $\mathrm{O}$. No difference in intestinal strontium absorption after oral or IV calcitriol in children with secondary hyperparathyroidism. The European Study Group on Vitamin D in Children with Renal Failure. Kidney International 200058 981-988. (doi:10.1046/j.1523-1755.2000. 00255.x)

43 Gallagher JC, Jindal P \& Lunette MS. Vitamin D does not increase Calcium absorption in young women: a randomized controlled trial. Journal of Bone and Mineral Research 2014 in press. (doi:10.1002/ jbmr.2121)

Received 2 November 2013

Revised version received 16 December 2013

Accepted 6 January 2014 